\title{
The haemato-metabolic profile of high producing dairy cows during the transition period
}

\author{
Manju Aswal, Shiv Prasad, Nishant Kumar*, Veenesh Rajpoot, and Mohan Mondal
}

Livestock Production Management Section, National Dairy Research Institute, Karnal, Haryana India

\begin{abstract}
ASWAL, M., S. PRASAD, N. KUMAR, V. RAJPOOT, M. MONDAL: The haemato-metabolic profile of high producing dairy cows during the transition period. Vet. arhiv 91, 249-259, 2021.
\end{abstract}

\section{ABSTRACT}

The objective of the present study was to assess the haematological [haemoglobin, packed cell volume (PCV), total erythrocyte count (TEC), erythrocytic indices, total leucocyte count (TLC) and differential leucocyte count (DLC)] changes and metabolic adjustment, viz. blood glucose, blood urea nitrogen (BUN), non-esterified fatty acid (NEFA) and cholesterol, in high-yielding Sahiwal and Karan Fries cows during the transition period. For this purpose, blood samples were collected from 8 pregnant Karan Fries crossbred cows and 8 pregnant Sahiwal cows on days -15, -7, 0 (the day of calving), +7 and +15 from calving, and used for estimation of haemoglobin, PCV, TLC, TEC, erythrocytic indices and DLC, and metabolic parameters, such as blood glucose, BUN, NEFA and cholesterol. It was found that haemoglobin concentrations, PCV and TEC increased significantly $(\mathrm{P}<0.01)$ up to the day of calving, and gradually decreased thereafter to reach pre-partum levels in the subsequent weeks post-calving. While the TLC, number of neutrophils and monocytes were found to increase $(\mathrm{P}<0.01)$, the number of lymphocytes decreased significantly $(\mathrm{P}<0.01)$ on the day of calving and then reached pre-partum levels after calving. No significant effect was observed on erythrocytic indices parameters. Blood glucose, BUN and NEFA levels showed an increasing trend $(\mathrm{P}<0.01)$ from 2 weeks pre-partum until the day of calving, and then decreased to the pre-partum level after calving. Unlike the other parameters, the plasma cholesterol level increased consistently from 2 weeks pre-partum to 2 weeks post-partum. In conclusion, the results of our study clearly show a definite pattern of the haematological and metabolic adjustment of high-producing dairy cows during the pre-partum to postpartum transition.

Key words: dairy cows; haematological; metabolic; post partum; transition period

\section{Introduction}

The transition period for dairy cows, defined as the period 3 weeks pre-calving to 3 weeks postcalving (GRUMMER, 1995; KOČILA et al., 2013; FOLNOŽIĆ et al. 2015; ĐURIČIĆ et al. 2020)), is the most critical phase of the post calving part. The transition period is important in terms of its influence on the health and subsequent performance of dairy cows, since cows undergo significant metabolic and physiological changes during this period (KOČILA et al., 2009; PICCIONE et al., 2012; TURK et al., 2016; KOVÁCS et al., 2020). This period is characterized by a substantial

\footnotetext{
*Corresponding author:

Nishant Kumar, PhD., Scientist, Livestock Research Centre, ICAR-NDRI, Karnal Phone: +9996268425; E-mail: drnishantvet78@gmail.com; Nishant.Kumar@icar.gov.in
} 
decline in feed intake around parturition with lipid mobilization, leading to elevated plasma NEFA and hepatic triglyceride (TG) content and protein mobilization (VAZQUEZ-ANON and BERTICS, 1994; SZENCI et al. 2018). The bodies of dairy cows undergo tremendous changes during the transition from late gestation to early lactation. The physiological changes occurring in body of dairy animals during this period have a profound effect on the metabolic profile of cows around calving (GRUMMER, 1995; KLECZKOWSKI et al. 2017; ALADROVIĆ et al. 2018; FOLNOŽIĆ et al. 2019b). During the transition period, a major change occurs in blood cell parameters as dairy cows undergo a tremendous set of metabolic adaptations from late pregnancy to early lactation. These changes are normally exquisitely coordinated by hormonal changes, to support the new physiological state of lactation (BELL, 1995; DOBRANIĆ et al. 2008; FOLNOŽIĆ et al., 2019a). Despite the remarkable output of research on the nutrition and physiology of transition cows, the transition period remains a problematic area on many dairy farms, and metabolic disorders continue to occur at economically important rates on commercial dairy farms (BURHANS et al., 2003; VINCE et al. 2017; HADŽIMUSIĆ and HRKOVIC POROBIJA, 2018) and the calving to first service interval depends on various factors, such as proper oestrus expression, good uterine health etc. (RAHEJA et al., 2018). Therefore, various attempts have been made to regulate post-partum reproductive performance through use of hormones and biological agents, but have proved ineffective due to their high costs and non-availability in time (SINGH et al., 2016). Some herbal mixture supplemented cows showed a shorter interval between calving and $1^{\text {st }}$ observed oestrus (KURI et al., 2019). Therefore, research into understanding the biology of transition cows will be useful for implementing management schemes on dairy farms to optimize production and profitability during this critical period. Since the hallmark of the transition period in dairy cattle is a dramatic change in nutrient demands needed for the fine coordination of the metabolism to meet the requirements for energy, glucose, amino acids following calving, the present study was undertaken with the objective of studying the changes in haematological and metabolic parameters during the peri-parturient period in high yielding Sahiwal and Karan Fries cows.

\section{Materials and methods}

Animal ethics approval. The experiment was approved by the Institutional Animal Ethics Committee, constituted as per the Article 13 of the CPCSEA-rules, laid down by the Government of India.

Experimental animals. High-yielding Karan Fries and Sahiwal cows ( $\mathrm{n}=8$ each), were selected according to their expected production ability (EPA), calculated on the basis of their previous lactation milk yield. The EPA of Karan Fries cows was $>4000 \mathrm{~kg} / 305$ days lactation and the EPA of Sahiwal cows was $>2000 \mathrm{~kg} / 305$ days lactation milk yield._A total of 16 animals in their last month of gestation were selected. During the research period, fodders such as Berseem, Oat, Mustard and Maize were given. The fodder supply was ad lib. A concentrate was fed @ $1.5 \mathrm{~kg}$ /day as the maintenance diet. Before parturition, dry pregnant animals were provided an additional $1 / 2$ to $1 \mathrm{~kg}$ concentrate during the last 2 to 3 weeks of gestation, over and above the maintenance requirements. After parturition, lactating animals were given additional concentrate @1.0 kg for every $2.5 \mathrm{~kg}$ of milk produced above the $5.0 \mathrm{~kg}$ daily yield, to meet their energy requirements. The concentrate mixture was fed in three parts to the cows separately at the time of milking (morning 5.00 to $6.00 \mathrm{AM}$, noon 12.00 to $1.00 \mathrm{PM}$ and evening 6.00 to $7.00 \mathrm{PM}$.).

Blood samples were collected via the jugular vein from selected animals early in the morning (6.00 AM to $7.00 \mathrm{AM}$ ) on days $-15,-7,0,+7$ and +15 of calving. Initially, 18 Karan Fries and 16 available Sahiwal cattle were used for the current study, from which blood samples were taken on days 15 and 7 before their expected date of calving. Of these, 8 Karan Fries and 8 Sahiwal cows were selected for the final study because we were able to take blood samples on exactly day 15 and day 7 before calving. Plasma and serum were separated according to the standard protocol. 
Haematology and blood metabolites estimation. The haematological parameters studied in the present experiment were: haemoglobin $(\mathrm{Hb})$, packed cell volume (PCV), total erythrocyte count (TEC), total leucocyte count (TLC), differential leucocyte count (DLC) and erythrocytic indices i.e. Mean Corpuscular Volume (MCV), Mean Corpuscular Haemoglobin (MCH) and Mean Corpuscular Haemoglobin Concentration (MCHC). Haemoglobin in the blood was estimated by Sahli's acid haematin method. PCV was estimated by the macrohematocrit method. TEC, TLC and DLC were estimated as per the standard protocol. Erythrocyte indices were calculated using the values of haemoglobin, PCV and TEC. Glucose in blood plasma was estimated by the end-point o-Toluidine method. The Blood Urea Nitrogen (BUN) was estimated according to RAHMATULLA and BOYDE (1980). The copper soap extraction method modified, by SHIPE and FOUNTAIN (1980), was adopted for determination of the plasma NEFA. Plasma cholesterol was estimated by oxidation by $\mathrm{FeCl}_{3}-\mathrm{H}_{2} \mathrm{SO}_{4}$, and the colour developed was measured by spectrophotometry.

Statistical analysis. The data has been presented as mean $\pm \mathrm{SE}$. The statistical analysis of the data on haematological (Haemoglobin, packed cell volume, total erythrocyte count, total leucocytes count, differential leucocytes count and erythrocytic indices i.e. mean corpuscular volume, mean corpuscular haemoglobin and mean corpuscular haemoglobin concentration) and metabolic parameters (Blood glucose, blood urea nitrogen, NEFA and plasma cholesterol) were carried out using least square analysis (2-way ANOVA) with interactions as described by SNEDECOR and COCHRAN (1989). Descriptive statistics (mean and standard deviation) were estimated for different parameters. Significance was considered at $\mathrm{P}<0.01$ level if not otherwise stated.

\section{Results}

Haematological parameters. Mean $( \pm \mathrm{SE})$ values of the haematological parameters (Erythrocytic series and leucocytic series) of Sahiwal and Karan Fries cattle are presented in Tables 1 and 2.

Haemoglobin concentration. The haemoglobin concentration increased from two weeks before calving to the day of calving, reached its highest value on the day of calving and then decreased to the normal level in the week following calving in both Sahiwal and Karan Fries cattle (Table 1).

Packed cell volume $(P C V)$. The PCV level increased significantly $(\mathrm{P}<0.01)$ up to the day of calving, reached its maximum value on the day of calving, followed by a steady reduction (Table 1).

Total erythrocyte count (TEC). There were significantly $(\mathrm{P}<0.01)$ higher values of TEC on the day of calving in both the breeds compared to the pre-partum and post-partum periods.

Erythrocytic indices. In the present study, no significant variation was observed in the erythrocytic indices in either Sahiwal or Karan Fries cows. MCV, $\mathrm{MCH}$ and $\mathrm{MCHC}$ were found to be unaffected during transition period.

Total and differential leucocyte counts. TLC increased significantly $(\mathrm{P}<0.01)$ from 2 weeks before calving until the day of calving, and then decreased in the first week after calving.

Metabolic profile. The mean $( \pm \mathrm{SE})$ values of the metabolic parameters of Sahiwal and Karan Fries cattle are presented in Table 3.

Blood glucose. There was a significant $(\mathrm{P}<0.01)$ variation in blood glucose levels, showing a sharp increase from two weeks pre-partum up to the day of calving, followed by sudden decrease in the first week post-partum in both Sahiwal and Karan Fries.

Blood urea nitrogen (BUN). BUN levels varied significantly $(\mathrm{P}<0.01)$ among the different stages and between the two breeds concerned.

Non esterified fatty acids (NEFA). The results of plasma NEFA concentration are presented in Table 3 . The NEFA concentration increased significantly $(\mathrm{P}<0.01)$ from 2 weeks pre-partum, and reached a peak level on the day of calving. It decreased significantly up to 2 weeks postpartum, compared to at calving. There was also a significant $(\mathrm{P}<0.01)$ difference in NEFA concentrations between the two breeds, showing higher levels in Karan Fries compared to Sahiwal.

Plasma cholesterol. Plasma cholesterol levels increased significantly from 2 weeks pre-partum to 2 weeks post-partum. 
M. Aswal et al.: The haemato-metabolic profile of high producing dairy cows during the transition period

Table 1. Mean ( \pm SE) haematological parameters (Erythrocytic series) of Sahiwal and Karan Fries cattle

\begin{tabular}{|c|c|c|c|c|c|c|}
\hline \multirow[b]{2}{*}{ Parameters } & \multirow[b]{2}{*}{ Breed } & \multicolumn{2}{|c|}{ Pre-partum } & \multirow{2}{*}{$\begin{array}{c}\text { Calving } \\
0 \text { day }\end{array}$} & \multicolumn{2}{|c|}{ Postpartum } \\
\hline & & - 15 day & - 7 day & & +7 day & +15 day \\
\hline \multirow{2}{*}{$\begin{array}{l}\text { Haemoglobin } \\
(\mathrm{Hb})(\mathrm{g} / \mathrm{dL})\end{array}$} & SW & $13.41 \pm 0.35^{\mathrm{a}}$ & $14.63 \pm 0.15^{\mathrm{b}}$ & $16.10 \pm 0.13^{c}$ & $14.20 \pm 0.23^{\mathrm{bd}}$ & $12.70 \pm 0.17^{\mathrm{ae}}$ \\
\hline & KF & $12.65 \pm 0.39^{a}$ & $14.1 \pm 0.33^{b}$ & $14.68 \pm 0.34^{\mathrm{c}}$ & $13.76 \pm 0.23^{\mathrm{bd}}$ & $12.27 \pm 0.20^{\mathrm{a}}$ \\
\hline \multirow{2}{*}{$\begin{array}{l}\text { Packed cell } \\
\text { volume } \\
(\mathrm{PCV})(\%)\end{array}$} & SW & $36.38 \pm 1.30^{\mathrm{ad}}$ & $39.38 \pm 0.75^{b}$ & $45.00 \pm 0.57^{\mathrm{c}}$ & $37.50 \pm 1.41^{\mathrm{ab}}$ & $33.25 \pm 0.88^{\mathrm{e}}$ \\
\hline & $\mathrm{KF}$ & $35.25 \pm 1.06^{\mathrm{ac}}$ & $37.89 \pm 1.56^{\mathrm{ab}}$ & $42.63 \pm 1.02^{\mathrm{c}}$ & $37.5 \pm 0.98^{\mathrm{ad}}$ & $33.0 \pm 0.63^{\mathrm{e}}$ \\
\hline \multirow{2}{*}{$\begin{array}{l}\text { Total } \\
\text { erythrocyte } \\
\text { count (TEC) } \\
\left(\mathrm{x} 10^{6} / \mu \mathrm{L}\right)\end{array}$} & SW & $6.64 \pm 0.26^{\mathrm{ae}}$ & $7.60 \pm 0.17^{\mathrm{bd}}$ & $8.70 \pm 0.21^{\mathrm{c}}$ & $7.23 \pm 0.25^{\mathrm{ad}}$ & $7.31 \pm 0.26^{\text {bde }}$ \\
\hline & $\mathrm{KF}$ & $5.95 \pm 0.14^{\mathrm{a}}$ & $7.19 \pm 0.28^{\mathrm{ab}}$ & $7.97 \pm 0.45^{\mathrm{c}}$ & $6.34 \pm 0.50^{\mathrm{ad}}$ & $6.47 \pm 0.37^{\mathrm{ae}}$ \\
\hline \multirow{2}{*}{$\begin{array}{l}\text { Mean } \\
\text { corpuscular } \\
\text { volume MCV } \\
\text { (fL) }\end{array}$} & SW & $55.10 \pm 1.93^{\mathrm{ad}}$ & $53.12 \pm 2.11^{\mathrm{ab}}$ & $52.22 \pm 1.40^{\mathrm{ac}}$ & $53.30 \pm 1.84^{\mathrm{cbd}}$ & $46.40 \pm 1.34^{\mathrm{e}}$ \\
\hline & $\mathrm{KF}$ & $59.24 \pm 1.15$ & $53.10 \pm 2.76$ & $54.55 \pm 3.18$ & $62.39 \pm 4.14$ & $51.79 \pm 1.98$ \\
\hline \multirow{2}{*}{$\begin{array}{l}\text { Mean } \\
\text { corpuscular } \\
\text { haemoglobin } \\
(\mathrm{MCH})(\mathrm{pg})\end{array}$} & SW & $20.35 \pm 0.72$ & $19.30 \pm 0.40$ & $18.57 \pm 0.41$ & $19.81 \pm 0.71$ & $17.50 \pm 0.54$ \\
\hline & $\mathrm{KF}$ & $21.45 \pm 0.75$ & $19.55 \pm 0.91$ & $19.26 \pm 0.98$ & $22.40 \pm 1.79$ & $18.98 \pm 0.99$ \\
\hline \multirow{2}{*}{$\begin{array}{l}\text { Mean } \\
\text { corpuscular } \\
\text { haemoglobin } \\
\text { concentration } \\
(\mathrm{MCHC}(\mathrm{g} / \mathrm{dL})\end{array}$} & SW & $34.32 \pm 2.10$ & $34.19 \pm 2.25$ & $33.53 \pm 2.15$ & $35.28 \pm 2.57$ & $35.39 \pm 2.87$ \\
\hline & $\mathrm{KF}$ & $36.06 \pm 1.29$ & $37.38 \pm 1.25$ & $36.88 \pm 0.98$ & $36.88 \pm 1.10$ & $37.24 \pm 0.50$ \\
\hline
\end{tabular}

a,b,c,de - Means with different superscripts in a row differ significantly $(\mathrm{P}<0.01)$

Table 2. Mean ( \pm SE) haematological (Leucocytic series) parameters of Sahiwal and Karan Fries cattle

\begin{tabular}{|c|c|c|c|c|c|c|}
\hline \multirow[b]{2}{*}{ Parameters } & \multirow[b]{2}{*}{ Breed } & \multicolumn{2}{|c|}{ Pre-partum } & \multirow{2}{*}{$\begin{array}{c}\text { Calving } \\
0 \text { day }\end{array}$} & \multicolumn{2}{|c|}{ Postpartum } \\
\hline & & -15 day & - 7 day & & +7 day & +15 day \\
\hline \multirow{2}{*}{$\begin{array}{l}\text { Total } \\
\text { Leucocyte } \\
\text { Count (TLC) } \\
\left(\times 10^{3} / \mu \mathrm{L}\right) \\
\end{array}$} & SW & $7.73 \pm 0.27^{\mathrm{a}}$ & $8.75 \pm 0.34^{\mathrm{a}}$ & $9.96 \pm 0.48^{\mathrm{b}}$ & $7.72 \pm 0.30^{\mathrm{ac}}$ & $7.90 \pm 0.31^{\mathrm{ad}}$ \\
\hline & $\mathrm{KF}$ & $7.81 \pm 0.54^{\mathrm{a}}$ & $10.18 \pm 0.73^{\mathrm{ab}}$ & $12.45 \pm 1.20^{\mathrm{bc}}$ & $7.10 \pm 1.10^{\mathrm{ad}}$ & $7.59 \pm 1.11^{\mathrm{ad}}$ \\
\hline \multirow{2}{*}{$\begin{array}{l}\text { Lymphocytes } \\
(\%)\end{array}$} & SW & $71.34 \pm 0.79^{a}$ & $64.75 \pm 0.77^{b}$ & $52.63 \pm 2.86^{\mathrm{c}}$ & $61.63 \pm 1.89^{d}$ & $66.75 \pm 1.73^{\mathrm{ad}}$ \\
\hline & $\mathrm{KF}$ & $69.12 \pm 0.97^{\mathrm{ae}}$ & $61.25 \pm 1.34^{b}$ & $50.87 \pm 2.24^{c}$ & $62.75 \pm 2.10^{\text {bd }}$ & $68.00 \pm 1.55^{\mathrm{de}}$ \\
\hline \multirow{2}{*}{ Neutrophil (\%) } & SW & $23.37 \pm 1.13^{\mathrm{a}}$ & $31.87 \pm 0.78^{\mathrm{a}}$ & $41.25 \pm 2.89^{c}$ & $33.75 \pm 2.18^{\mathrm{a}}$ & $27.75 \pm 1.48^{a}$ \\
\hline & $\mathrm{KF}$ & $25.50 \pm 1.10^{\mathrm{a}}$ & $33.25 \pm 0.90^{\mathrm{b}}$ & $42.50 \pm 1.92^{c}$ & $33.00 \pm 1.93^{\text {bd }}$ & $27.25 \pm 1.69^{\mathrm{a}}$ \\
\hline \multirow{2}{*}{ Eosinophil (\%) } & SW & $2.62 \pm 0.32$ & $2.00 \pm 0.41$ & $2.75 \pm 0.16$ & $2.25 \pm 0.16$ & $2.88 \pm 0.35$ \\
\hline & $\mathrm{KF}$ & $2.62 \pm 0.38$ & $2.99 \pm 0.41$ & $3.25 \pm 0.37$ & $2.62 \pm 0.18$ & $2.37 \pm 0.46$ \\
\hline \multirow{2}{*}{ Basophil (\%) } & SW & $1.20 \pm 0.25$ & $1.00 \pm 0.16$ & $1.00 \pm 0.19$ & $1.00 \pm 0.13$ & $1.00 \pm 0.18$ \\
\hline & $\mathrm{KF}$ & $0.375 \pm 0.18$ & $0.50 \pm 0.19$ & $0.50 \pm 0.26$ & $0.375 \pm 0.18$ & $0.25 \pm 0.16$ \\
\hline \multirow{2}{*}{ Monocyte (\%) } & SW & $2.13 \pm 0.23^{\mathrm{a}}$ & $1.50 \pm 0.27^{\mathrm{a}}$ & $3.13 \pm 0.23^{\mathrm{b}}$ & $2.25 \pm 0.31^{\mathrm{c}}$ & $2.25 \pm 0.25^{\mathrm{c}}$ \\
\hline & $\mathrm{KF}$ & $1.87 \pm 0.35^{\mathrm{a}}$ & $1.75 \pm 0.25^{\mathrm{ac}}$ & $3.00 \pm 0.38^{\mathrm{b}}$ & $1.62 \pm 0.26^{\mathrm{ac}}$ & $2.00 \pm 0.27^{\mathrm{ad}}$ \\
\hline
\end{tabular}

a,b,c,d,e - Means with different superscripts in a row differ significantly $(\mathrm{P}<0.01)$ 
M. Aswal et al.: The haemato-metabolic profile of high producing dairy cows during the transition period

Table 3. Mean \pm SE of the metabolic parameters of Sahiwal and Karan Fries cattle during the peripartum period

\begin{tabular}{|c|c|c|c|c|c|c|}
\hline \multirow[b]{2}{*}{ Parameters } & \multirow[b]{2}{*}{ Breed } & \multicolumn{2}{|c|}{ Pre-partum } & \multirow{2}{*}{$\begin{array}{c}\text { Calving } \\
0 \text { day }\end{array}$} & \multicolumn{2}{|c|}{ Postpartum } \\
\hline & & -15 day & -7 day & & +7 day & +15 day \\
\hline \multirow{2}{*}{$\begin{array}{l}\text { Glucose } \\
\text { (mg/dL) }\end{array}$} & SW & $53.87 \pm 2.39^{\mathrm{a}}$ & $60.75 \pm 1.64^{\mathrm{b}}$ & $86.12 \pm 1.21^{\mathrm{c}}$ & $53.62 \pm 1.98^{\mathrm{ad}}$ & $63.00 \pm 2.52^{\text {be }}$ \\
\hline & $\mathrm{KF}$ & $56.63 \pm 1.28^{\mathrm{a}}$ & $64.25 \pm 1.11^{\mathrm{b}}$ & $77.12 \pm 1.67^{\mathrm{c}}$ & $49.37 \pm 1.61^{\mathrm{d}}$ & $56.25 \pm 1.00^{\mathrm{a}}$ \\
\hline \multirow{2}{*}{$\begin{array}{l}\text { Blood Urea } \\
\text { Nitrogen } \\
(\mathrm{BUN}) \\
(\mathrm{mg} / \mathrm{dL})\end{array}$} & SW & $30.61 \pm 0.77^{\mathrm{a}}$ & $35.66 \pm 0.74^{b}$ & $42.71 \pm 0.67^{c}$ & $35.48 \pm 1.12^{\mathrm{bd}}$ & $50.14 \pm 1.80^{\mathrm{e}}$ \\
\hline & $\mathrm{KF}$ & $34.38 \pm 0.79^{a}$ & $43.44 \pm 1.68^{\mathrm{b}}$ & $50.19 \pm 1.37^{\mathrm{c}}$ & $36.38 \pm 0.67^{\mathrm{a}}$ & $43.89 \pm 1.35^{\text {bd }}$ \\
\hline \multirow{2}{*}{$\begin{array}{l}\text { Non Esterified } \\
\text { Fatty Acid } \\
(\text { NEFA) } \\
(\mu \mathrm{mol} / \mathrm{L})\end{array}$} & SW & $277.28 \pm 5.59^{a}$ & $314.03 \pm 5.31^{b}$ & $366.88 \pm 4.68^{c}$ & $336.08 \pm 3.50^{\mathrm{d}}$ & $316.00 \pm 1.63^{\text {be }}$ \\
\hline & $\mathrm{KF}$ & $287.74 \pm 3.36^{\mathrm{a}}$ & $362.50 \pm 0.13^{b}$ & $438.78 \pm 9.12^{c}$ & $388.41 \pm 1.54^{\mathrm{d}}$ & $366.35 \pm 3.82^{\text {be }}$ \\
\hline \multirow{2}{*}{$\begin{array}{l}\text { Cholesterol } \\
(\mathrm{mg} / \mathrm{dL})\end{array}$} & SW & $124.22 \pm 1.82^{\mathrm{a}}$ & $140.20 \pm 2.58^{b}$ & $170.39 \pm 3.70^{c}$ & $192.65 \pm 1.84^{\mathrm{d}}$ & $202.24 \pm 1.16^{\mathrm{de}}$ \\
\hline & $\mathrm{KF}$ & $124.13 \pm 2.19^{a}$ & $138.03 \pm 2.05^{b}$ & $168.15 \pm 1.89^{c}$ & $194.80 \pm 1.18^{\mathrm{d}}$ & $230.00 \pm 2.45^{\mathrm{e}}$ \\
\hline
\end{tabular}

a,b,c,d,e - Means with different superscript in a row differ significantly $(\mathrm{P}<0.01)$

\section{Discussion}

Haemoglobin concentration. Our results are in agreement with PATEL et al. (2017), who observed higher levels of haemoglobin from 30 days before calving to the day of calving, and then a reduction in its level, back to the normal in the subsequent days. The higher levels of haemoglobin on the day of calving and immediately after calving denote the body tissue's increased requirement for energy for accomplishment of all the physiological processes related to calving. NAZIFI et al. (2008) also reported a similar pattern of changes in haemoglobin concentrations at the time of calving in dairy cattle and KORNMATITSUK et al. (2001) reported that haemoglobin content increased at the time of calving in dairy heifers. In the early lactation period we observed lower haemoglobin levels, which might be due to the lower rate of erythropoiesis in these animals (KUMAR and PACHAURI, 2000) or to the mammary tissues' higher level of haemoglobin requirement for milk synthesis, and the concomitant rise in blood flow to the mammary glands (EL NOUTY et al., 1986). ELSHAHAWY and ABDULLAZIZ (2017) reported that haemoglobin was significantly higher in peri-parturient cows at 2 weeks before calving than in post-parturient cows in the first and third weeks after calving.
Packed cell volume (PCV). An increased level of $\mathrm{PCV}$ around calving has been reported by NAZIFI et al. (2008) in dairy cattle. Higher PCV immediately before calving may indicate the requirement of higher red cell volume to carry more oxygen to meet the tissues' energy requirement at the time of calving (JAIN, 1996). ROWLANDS et al. (1975) also reported variations in PCV in relation to the stages of lactation and/or gestation. The PCV level is positively correlated with TEC, TLC and blood metabolites.

Total erythrocyte count (TEC). There was significant increase $(\mathrm{P}<0.05)$ in TEC on the day of calving in KF cows, which might be due to erythropoiesis and the slow destruction of erythrocytes during the transition period. However, the TEC level decreased to pre-partum levels one week after calving (KUMAR et al., 2018). A similar pattern of changes in TEC was also reported by NAZIFI et al. (2008) in transition dairy cows.

Total and differential leucocyte counts. A significant increase in TLC on the day of calving was mainly the result of an increase in the neutrophil count. In the present study, neutrophils and monocytes increased and lymphocytes decreased on the date of calving, suggesting a 
positive correlation between TLC and neutrophils and monocytes, and a negative correlation with lymphocytes in both Sahiwal and Karan Fries. There was no significant change in the proportion of eosinophils and basophils. The TLC was within the normal range, as also reported by JAIN (1986) in cattle. The increase in TLC, the neutrophil count and the N/L ratio on the day of calving may be stimulated by cortisol release in the highly stressful condition (KULBERG et al., 2002). The pattern of changes in TLC and DLC in the present study was similar to that reported by MEGLIA et al. (2001) in periparturient dairy cows. KORNMATITSUK et al. (2001) also reported similar results for TLC, polymorphonuclear cells and mononuclear cells in dairy heifers. The increase in blood neutrophils in high producing cows may be due to stress, and these neutrophils will migrate to the mammary glands to protect them from intra-mammary infection during the transition period. PATHAN et al. (2015) reported that TLC increased during the pre-partum from day 7 in dairy animals, with the peak observed at calving, and it began to decrease after calving. ABDELRAZEK et al. (2018) reported that TLC showed a more significant $(\mathrm{P} \leq 0.05)$ increment in the post-partum period than in the pre-partum period. The percentage of lymphocytes was significantly $(\mathrm{P} \leq 0.05)$ higher in the pre-partum period compared to the time of calving. However, the percentage of postpartum lymphocytes was non-significantly altered when compared to the pre-partum period and the time of parturition. The percentage of monocytes showed a significant $(\mathrm{P} \leq 0.05)$ increase at calving when compared to the pre-partum and post-partum periods. The percentage of eosinophils demonstrated non-significant changes throughout the transition period in the buffaloes.

\section{Metabolic profile.}

Blood glucose. The increased glucose level at calving time could be due to increased hepatic gluconeogenesis (REYNOLDS et al., 2003). After calving, the demand for glucose increases significantly, and cows adapt to this requirement by gluconeogenesis from propionates, amino acids, lactate and glycerol (DRACKLEY et al., 2001). In the present study, blood glucose was positively correlated with BUN, NEFA and cholesterol in the
Sahiwal and Karan Fries cows. This suggests that amino acids from protein catabolism or glycerol released during lipolysis into the adipose tissue could contribute to hepatic gluconeogenesis during the transition period. It further supports the increase in the protein concentration in cows, and triggers more intense gluconeogenesis and subsequently higher glucose levels (RASTANI et al., 2006). The transient fall in glucose levels in the first week of lactation could be the result of high demands for lactose synthesis and insufficient gluconeogenesis (DOEPEL et al., 2002), mainly because energy losses could not be fully compensated by energy intake. Karan Fries cows were not able to improve their glucose levels compared to Sahiwal in the postpartum period. The glucose concentration is regulated by various hormones, such as insulin, cortisol, glucagon, somatotropin and adrenalin, and consequently blood glucose levels depend on the nutritive values of the diet, on social or environmental stress conditions, as well as on physiological phases (BORGHESE, 2005). PANDE et al. (2016) reported that the higher levels of glucose recorded on the day of calving may be the result of transient stress (cortisol mediation) associated with parturition.

Blood urea nitrogen (BUN). The BUN levels increased with the advancement of the gestation period, reaching the highest value on the day of calving and then decreasing slightly 7 days after calving, but then rising slightly 15 days postcalving. The increased BUN concentrations could be due to a high energy deficit due to ammonia conversion by the liver and urea excretion in highyielding animals. The rise in BUN levels may also denote an imbalance between protein and energy levels in the cows' diet (DHALI, 2001). Further, BUN levels are influenced by renal function, days in milk (CAMPANILE et al., 1997), by diet (DHALI et al., 2006) and by the season (DHALI et al., 2006). Nutritional factors influence BUN levels, such as protein intake, both degradable and non-degradable protein, in relation to ruminal fermentable carbohydrates; the ratios of adsorbed amino acids as related to the metabolic demand etc. In the present study, the BUN level is positively correlated with NEFA and cholesterol. RASTANI 
et al. (2006) reported a relationship between plasma NEFA concentration and BUN at two weeks after calving $(\mathrm{P}<0.02)$. The relationship between BUN, feed efficiency, body weight loss and plasma NEFA reflects the energy status of the cow, and protein mobilization as possible determinants of BUN concentration. ABDELRAZEK et al. (2018) reported that the concentrations of NEFA and BUN were significantly elevated $(\mathrm{P} \leq 0.05)$ in the postpartum period as compared to the pre-partum period. The higher level of BUN may also be because of the high availability of leguminous fodder, called Berseem (Trifolium alexandrinum), during the period of sampling. Berseem is an annual clover, cultivated mostly in sub-tropical regions and used as fodder, mainly for cattle and buffalo. Milk urea concentration, which is directly correlated to BUN, has been suggested as a potential management tool to monitor protein and energy feeding efficiency, and the reproductive performance of herds (DHALI, 2001).

Non esterified fatty acids (NEFA). The primary homeorhetic adaptation of lipid metabolism to lactation is the mobilization of body fat stores in the form of NEFA, during the period of negative energy balance in early lactation. NYMAN et al. (2008) reported significant breed differences for plasma NEFA concentrations. An increase in the concentration of plasma NEFA results from the mobilization of lipids, which increases gradually in the pre-partum transition period, but more rapidly in the last 3 days of gestation, due to energy deficit or hormonal changes (DYK et al., 1995). Increased lipolysis triggered by hormonal changes, catecholamine release and the increased activity of the sympathetic nervous system around calving could result in a significant increase in NEFA concentration at parturition (GRUM et al., 1996). The energy balance has been recognized as the main determinant of plasma NEFA concentrations. Cows in early lactation have higher energy requirements that cannot be supported by dietary intake, and the animals use body fat as a source of energy, as our results indicate high NEFA levels in the post partum period.

In the case of Sahiwal and Karan Fries, the NEFA level was positively correlated with blood glucose, BUN, cholesterol, Hb, TEC and TLC. The pattern of change and the range of plasma NEFA were in agreement with DRACKLEY (2001) for transition dairy cows. DRACKLEY (2001) reported that NEFA levels increased sharply from 2 to 3 days before calving and generally reached a peak on the day of calving, due to hormonal changes and the stress of calving. After calving, NEFA usually shows a downward trend, and by 3 weeks after calving, it will return to normal. The ratio of growth hormone to insulin is high in the blood of cows in early lactation, and induces the mobilization of fatty acids from adipose tissue triglycerides. The sensitivity of adipose tissue to lipolytic signals (epinephrine and norepinephrine) is also greatly enhanced in early lactation (UNDERWOOD et al., 2003). Fatty acids released from adipose tissue circulate as NEFA, which is a major source of energy to the cow during this period. The percentage of blood NEFA utilized by the liver is fairly constant, and excessive NEFA is converted to ketone bodies.

Plasma cholesterol. Cholesterol levels were comparable and positively correlated with BUN and NEFA. GRASSO et al. (2004) reported no significant difference in cholesterol when comparing Brahman and Angus cows. Similarly, KUMAR et al. (2018) reported that the concentrations of cholesterol in mid-lactation animals were significantly $(\mathrm{P} \leq 0.05)$ higher than in early lactation and dry animals. ASHMAWY (2015) and LONE et al. (2003) revealed that the higher levels of cholesterol with advancement of lactation are a physiological adjustment to meet the lactation requirements. ABAYAWANSA et al. (2013) noticed a significantly higher serum cholesterol concentration during the pre-calving period, and the low concentration at calving could be due to the high demand for adrenal corticosteroid and placental steroid synthesis, as well as colostrum and milk synthesis. Similarly, PATEL et al. (2018) reported that the high cholesterol levels reported in mid lactation might be due to lower levels of thyroxin in the blood. Increasing cortisol levels were observed with the advancement of the gestation period. Serum cholesterol levels are usually considered as an indicator of good hepatic lipoprotein production. Total cholesterol indirectly reflects the degree of exogenous energy 
available, and hepatic functionality. Its levels rise during a moderate negative energy balance, such as in lactation, low temperatures and a high thermal range (CAMPANILE et al., 1994).

\section{Conclusion}

In conclusion, there were significant differences in blood glucose, BUN, NEFA and cholesterol levels, and less conspicuous changes in haematological parameters in both Sahiwal and Karan Fries cows during the peri-partum period. The results of the present study clearly show the haemato-metabolic adjustment of Karan Fries and Sahiwal cows during the transition phase. This basic information, thus generated, may be of great use for better management of high-yielding dairy cows during the transition period.

\section{References}

ABAYAWANSA, W. D., S. PRABHAKAR, A. K. SINGH, P. S. BRAR (2013): Seasonal variations in blood metabolic profiles during peri and early postpartum period in winter and summer calved buffaloes. Indian J. Anim. Reprod. 34, 61-70.

ABDELRAZEK, H., T. A. ISMAIL, F. E. EL-AZZAZI, D. H. ELSAYED (2018): Hematological and metabolic alterations in Egyptian buffaloes during transition period. Egypt. Acad. J. Biol. Sci., C Physiol. 10, 69-78.

DOI: $10.21608 /$ eajbsc.2018.13657

ALADROVIĆ, J., M. PAVKOVIĆ, B. BEER-LJUBIĆ, L. VRANKOVIĆ, Z. STOJEVIĆ (2018): Metabolic profile in Holstein dairy cow herd. Vet. stn. 49, 9-18. (In Croatian).

ASHMAWY, N. A. (2015): Blood metabolic profile and certain hormones concentrations in Egyptian buffalo during different physiological states. Asian J. Anim. Vet. Adv. 10, 271-280.

DOI: 10.3923 /ajava.2015.271.280

BELL, A. W. (1995): Regulation of organic nutrient metabolism during transition from late pregnancy. J. Anim. Sci. 73, 2804-2819.

DOI: $10.2527 / 1995.7392804 x$

BORGHESE, A (2005): Buffalo production and research. REU technical series 67. FAO, United Nations, Rome.

BURHANS, W. S., A. W. BELL, R. NADEAU, J. R. KNAPP (2003): Factors associated with transition cow ketosis incidence in selected New England herds. J. Dairy Sci. 86, Suppl., 247.

CAMPANILE, G., R. DIPALO, A. D'ANGELO (1997): Profilo metaboliconel buffalo. Bubalus bubalis, Suppl. No. 4, 236249.
CAMPANILE, G., R. DIPALO, C. DI MEO, M. STAINO, L. ZICARELLI (1994): Metabolic profile in Italian buffaloes. Proc. Fourth World Buffalo Congress, Sao Paolo, Brazile. 257-259.

DHALI, A., R. K. MEHLA, S. K. SIROHI, A. MECH, M. KARUNAKARAN (2006): Monitoring feeding adequacy in dairy cows using milk urea and milk protein contents under farm conditions. Asian-Aust. J. Anim. Sci. 19, 17421748 .

DOI: $10.5713 /$ ajas.2006.1742

DHALI, A. (2001): Studies on the effect of feeding management system on blood and milk urea nitrogen concentration in dairy cattle. Ph.D. thesis submitted to National Dairy Research Institute, Karnal.

DOBRANIĆ, V., B. NJARI, M. SAMARDŽIJA, B. MIOKOVIĆ, R. RESANOVIĆ (2008): The influence of the season on the chemical composition and the somatic cell count of bulk tank cow's milk. Vet. arhiv 78, 235-242.

DOEPEL, L., H. LAPIERRE, J. J. KENNEKY (2002): Peripartum performance and metabolism of dairy cows in response to prepartum energy and protein intake. J. Dairy Sci. 85, 2315 - 2334.

DOI: $10.3168 /$ jds.s0022-0302(02)74312-9

DRACKLEY, J. K., T. R. OVERTON, G. N. DOUGLAS (2001): Adaptations of glucose and long chain fatty acid metabolism in liver of dairy cows during the periparturient period. J. Dairy Sci. 84, E100 - E112.

DOI: $10.3168 /$ jds.s0022-0302(01)70204-4

DRACKLEY, J. K. (2001): Nutritional and management of transition dairy cows: An integration of nutrition and stress physiology. In: Proc. California Anim. Nutri. Conf., Frensno, CA. California Grain and Feed Assoc., Sacramento, CA. 113-134

ĐURČIĆ, D., B. B. LJUBIĆ, S. VINCE, R. TURK, H VALPOTIĆ, I. ŽURA ŽAJA, N. MAĆEŠIĆ, M. BENIĆ, I. GETZ, M. SAMARDŽIJA (2020): Effects of dietary clinoptilolite supplementation on $\beta$-hydroxybutirate serum level and milk fat to protein ratio during early lactation in Holstein-Friesian cows. Micropor. Mesopor. Mat. 292, $109-766$

DOI: 10.1016/j.micromeso.2019.109766

DYK, P. B., R. S. EMERY, J. L. LIESMAN, H. F. BUCHOLTZ, M. J. VANDE HAAR (1995): Prepartum non-esterified fatty acids in plasma are higher in cows developing periparturient health problems. J. Dairy Sci. 78 (Suppl. 1), 264.

EL NOUTY, F. D., G. A. HASSAN, M. H. SALEM (1986): Effect of season and level of roduction on haematological values in Holstein cows. Indian J. Anim. Sci. 56, 346350 .

ELSHAHAWY, I. I., I. A. ABDULLAZIZ (2017): HematoBiochemical Profiling in Relation to Metabolic Disorders in Transition Dairy Cows. Alex. J. Vet. Sci. 55, 25-33.

DOI: $10.5455 /$ ajvs. 275430 
FOLNOŽIĆ, I., R. TURK, D. ĐURIČIĆ, S. VINCE, J. PLEADIN, Z. FLEGAR-MEŠTRIĆ, H. VALPOTIĆ, T. DOBRANIĆ, D. GRAČNER, M. SAMARDŽIJA (2015): Influence of body condition on serum metabolic indicators of lipid mobilization and oxidative stress in dairy cows during the transition period. Reprod. Domest. Anim. 50, 910-917.

DOI: $10.1111 /$ rda. 12608

FOLNOŽIĆ, I., M. SAMARDŽIJA, D. ĐURIČIĆ, S. VINCE, S. PERKOV, S. JELUŠIĆ, H. VALPOTIĆ, B. BEER LJUBIĆ, M. LOJKIĆ, D. GRAČNER, I. ŽURA ŽAJA, N. MAĆEŠIĆ, J. GRIZELJ, T. DOBRANIĆ, G. REDŽEPI, Z. ŠOSTAR, R. TURK (2019a): Effects of in-feed clinoptilolite treatment on serum metabolic and antioxidative biomarkers and acute phase response in dairy cows during pregnancy and early lactation. Res. Vet. Sci. $127,57-64$

DOI: $10.1016 /$ j.rvsc.2019.10.010

FOLNOŽIĆ, I., D. ĐURIČIĆ, I. ŽURA ŽAJA, S. VINCE, S. PERKOV, R. TURK, H. VALPOTIĆ, D. GRAČNER, N. MAĆEŠIĆ, M. LOJKIĆ, M. KOVAČIĆ, M. SAMARDŽIJA (2019b): The influence of dietary clinoptilolite on blood serum mineral profile in dairy cows. Vet. arhiv 89, 447-462 DOI: $10.24099 /$ vet.arhiv.0662

GRASSO, F., G. M. TERZANO, G. DE ROSA, C. TRIPALDI, F. NAPOLILAN (2004): Influence of housing conditions and calving distance on blood metabolites in water buffalo cows. Italian J. Anim. Sci. 3, 273-287.

DOI: $10.4081 /$ ijas.2004.275

GRUM, D. E., J. K. DRACKLEY, R.S. YOUNKER, D. W. LACOUNT, J. J. VEENHUIZEN (1996): Nutrition during the dry period and hepatic lipid metabolism of periparturient dairy cows. J. Dairy Sci. 79, 1850-1864.

DOI: $10.3168 /$ jds.s0022-0302(96)76553-0

GRUMMER, R. R. (1995): Impact of changes in organic nutrient metabolism on feeding the transition dairy cow. J. Anim. Sci. 73, 2820-2833.

DOI: $10.2527 / 1995.7392820 x$

HADZIMUSIC, N., A. HRKOVIC POROBIJA (2018): Effects of seasonal and geographical variation on blood biochemistry parameters of dairy cows. Vet stn. 49, 229237. (In Croatian).

JAIN, N. C. (1986): In Schalm's Veterinary Hematology. Lea and Febiger, Philadelphia, 821-837.

JAIN, N. C. (1996): Shalm's Veterinary Haematology, 5th edn. Philadelphia: Lea and Febiger.

KANEKO, J. J. (1980): Clinical Biochemistry of Domestic Animals. 3rd Ed. Academic press, New York.

KLECZKOWSKI, M., W.KLUCINSKI, M. CZERSKI, E. KUDYBA (2017): Association between acute phase response, oxidative status and mastitis in cows. Vet. stn. 48, 177-186.
KOČILA, P., M. SAMARDŽIJA, T. DOBRANIĆ, D. GRAČNER, V. DOBRANIĆ, N. PRVANOVIĆ, Ž. ROMIĆ, N. FILIPOVIĆ, N. VUKOVIĆ, D. ĐURIČIĆ (2009): Einfluss der Energiebilanz auf die Reproduktionsfähigkeit von Holsteiner Kühen im Puerperium. Tierärztl. Umschau 64, 471-477.

KOČILA, P., A. JANŽEK, D. GRAČNER, T. DOBRANIĆ, D. ĐURIČIĆ, N. PRVANOVIĆ, N. FILIPOVIĆ, G. GREGURIĆ GRAČNER, LJ. BEDRICA, F. MARKOVIĆ, M. HORVAT, M. SAMARDŽIJA (2013): Progesterone concentration and energy balance infl uence on dairy cows with different milk yield during puerperium. Tierärtzl. Umsch. 68, 266-274

KORNMATITSUK, B., K. K. ONIGSSON, H. KINDAHL, H. GUSTAFSSON, M. FORSBERG, A. MADEJ (2001): Clinical signs and hormonal changes in dairy heifers after induction of parturition with prostaglandin F2 $\alpha$. J. Vet. Med. 47, 395-409.

DOI: 10.1046/j.1439-0442.2000.00299.x

KOVACS, L., L. ROZSA, M. PALFFY, P. HEJEL, W. BAUMGARTNER, O. SZENCI (2020): Subacute ruminal acidosis in dairy cows - physiological background, risk factors and diagnostic methods. Vet. stn. 51, 5-17.

DOI: $10.46419 /$ vs.51.1.1

KULBERG, S., A. K. STORSET, B. HERINGSTAD, H. J. S. LARSEN (2002): Reduced levels of total leukocytes and neutrophils in norwegian cattle selected for decreased mastitis incidence. J. Dairy Sci. 85, 3470-3475.

DOI: $10.3168 /$ jds.s0022-0302(02)74435-4

KUMAR, B., S. P. PACHAURI (2000): Haematological profile of crossbred dairy cattle to monitor herd health status at medium elevation in Central Himalayas. Res. Vet. Sci. 69, 141-145

DOI: $10.1053 /$ rvsc. 2000.0400

KUMAR, V., Y. S. RANA, P. KUMAR, R. JHAMBH, V. K. JAIN (2018). Assessment of metabolic parameters of dairy buffaloes from an organized dairy farm during different phases of lactation. Parameters. Pharma Innovation 7, 442446

KURI, P., P. KUMAR, N. KUMAR, A. AGGARWAL, M. SINGH (2019): effect of poly-herbal mixture supplementation during post partum period on feed intake and reproductive performance of Sahiwal cows. Indian J. Anim. Nutrit. 36, 35-39.

DOI: $10.5958 / 2231-6744.2019 .00006 .9$

LONE, A. G., C. SINGH, S. P. S. SINGHA (2003): Plasma protein profile of neonatal buffalo calves in relation to the protein profile of colostrum/milk during first week following parturition. Asian-Australas J. Anim. Sci. 16, 348-352.

DOI: $10.5713 /$ ajas.2003.348

MEGLIA, G. E., A. JOHANNISSON, L. PRTERSSON, K. P. WALLER (2001): Changes in some blood micronutrients, 
leukocytes and neutrophil expression adhesion molecules in periparturient dairy cows. Acta Vet. Scand. 42, 139-150. DOI: $10.1186 / 1751-0147-42-139$

NAZIFI, M. R. AHMADI, H. R. GHEISARI (2008): Hematological changes of dairy cows in postpartum period and early pregnancy. J. Comp. Clin. Path. 17, 157-153.

DOI: $10.1007 / \mathrm{s} 00580-008-0730-6$

NYMAN, A. K., U. EMANUELSON, K. HOLTENIUS. K. L INGVARTSEN, T. LARSEN, K. P. WALLER (2008): Metabolites and immune variables associated with somatic cell counts of primiparous dairy cows. J. Dairy. Sci. 91, 2996-3009.

DOI: $10.3168 /$ jds.2007-0969

PANDE, N., R. AGRAWAL, O. P. SHRIVASTAVA, M. SWAMY (2016): Alterations in haemato-metabolic status and body condition score of buffaloes during the transition period. Livest. Sci. 7, 122-125.

PICCIONE, G., V. MESSINA, S. MARAFIOTI, S. CASELLA, C. GIANNETTO, F. FAZIO (2012): Changes of mehaematochemical parameters in dairy cows during late gestation, post partum, lactation and dry periods. Vet. Med. Zoot. 58, 59-64.

PATHAN, M. M., M. KAUR, A. K. MOHANTY, S. KAPILA, A. K. DANG (2015): evaluation of neutrophil competence and activity of cows and buffaloes around peripartum. J. Appl. Anim. Res. 43, 61-68.

PATEL, B., N. KUMAR, V. JAIN, F. KUMAR, A. HM, M. A. NAIK, S. S. LATHWAL (2017): Haematological status of Karan Fries cows during transition period in hot humid condition. Int. J. Environ. Sci. Technol. 6, 793-797.

PATEL, B., N. KUMAR, V. JAIN, N. RAHEJA, S. K. YADAV, N. KUMAR, S. V. SINGH, (2018): Effect of zinc supplementation on hormonal and lipid peroxidation status of peri-parturient Karan Fries cows during heat stress condition. Indian J Anim. Res. 52, 513-517.

DOI: 10.18805/ijar.v0iof.9177

RAHMATULLAH, H., T. R. C. BOYDE (1980): Improvement in the determination of urea diacetylmonoxime: method with or without deprotinization. China Chim. Acta 107, 3-9.

RASTANI, R. R., N. E. LOBOS, M. J. AGUERRE (2006): Relationship between blood urea nitrogen and energy balance as measure of tissue mobilization in Holstein cows during the periparturient period. The professional animal scientists $22,382-385$.

DOI: $10.15232 / \mathrm{s} 1080-7446(15) 31131-1$

RAHEJA, N., N. KUMAR, B. PATEL, S. S. LATHWAL (2018): Effect of dietary betaine on reproductive performance of Karan Fries cows during hot humid season. Int. J. Curr. Microbiol. Appl. Sci. 7, 1451-1460.

DOI: $10.20546 /$ ijcmas.2018.709.174
REYNOLDS, C. K., P. C. AIKMAN, B. LUPOLI, D. J. HUMPHRIES, D. E. BEEVER (2003): Splanchnic metabolism of dairy cows during the transition from late gestation through early lactation. J. Dairy Sci. 86, 12011217.

DOI: $10.3168 /$ jds.s0022-0302(03)73704-7

ROWLANDS, G. J., R. MANSTON, R. M. POCOCK, S. M. DEW (1975): Relationship between stage of lactation and pregnancy and blood composition in a herd of dairy cows and the influences of seasonal changes in management on these relationships. J. Dairy Res. 42, 349-362.

DOI: $10.1017 / \mathrm{s} 0022029900015399$

SHIPE, W. F., K. B. FOUNTAIN (1980): Modified copper soap solvent extraction method for measuring free fatty acids in milk. J. Dairy Sci. 63, 193-198.

DOI: $10.3168 /$ jds.s0022-0302(80)82913-4

SINGH, P. K., M. L. KAMBOJ, N. KUMAR (2016): Effect of dummy calf, weaning and suckling on the reproductive performance of post-partum Murrah buffaloes. Indian J. Anim. Res. 50, 265-267.

DOI: $10.18805 /$ ijar.9298

SNEDECOR, G. W., G. W. COCHRAN (1989): Statistical methods. 8th Ed., Iowa State Univ. Press, Ames., Iowa.

SZENCI, O., Z. SZELENYI, L. LENART, D. BUJAK, L.KOVACS, L. FRUZSINA KEZER, A. HORVÁTH (2018): Importance of monitoring the peripartal period to increase reproductive performance in dairy cattle. Vet. stn. 49, 297-307.

TURK, R., I. FOLNOŽIĆ, D. ĐURICIC, S. VINCE, Z. FLEGAR-MEŠTRIĆ, T. DOBRANIĆ, M. SAMARDŽIJA (2016): Relationship between paraoxonase-1 activity and lipid mobilisation in transition dairy cows. Vet. arhiv 86, 601-612.

DOI: $10.1111 /$ rda. 12608

UNDERWOOD, J. P., J. K. DRACKLEY, G. E. DAHL, T. L. ACHTUNG (2003): Responses to epinephrine challenges in the peripartal Holstein cow fed two amounts of metabolizable protein in pre-partum diets. J. Dairy Sci. 86, 106.

VAZQUE-ANON, M., S. BERTICS (1994): Peri-partum liver triglycerides and plasma metabolites in dairy cows. J. Dairy Sci. 77, 1521-1528.

DOI: 10.3168/jds.s0022-0302(94)77092-2

VINCE, S., D. ĐURIČIĆ, H. VALPOTIĆ, D. GRAČNER, I. FOLNOŽIĆ, B. ŠPOLJARIĆ, M. SAMARDŽIJA (2017): Risk factors and prevalence of subclinical ketosis in dairy cows in Croatia. Vet. arhiv 87, 13-24.

DOI: $10.24099 /$ vet.arhiv.0662 
Received: 6 April 2020

Accepted: 9 June 2020

\section{ASWAL, M., S. PRASAD, N. KUMAR, V. RAJPOOT, M. MONDAL: Hemato-metabolički profil visokoproizvodnih mliječnih krava za vrijeme prijelaznog razdoblja. Vet. arhiv 91, 249-259, 2021. \\ SAŽETAK}

Cilj ovoga istraživanja bio je procijeniti hematološke promjene i metaboličku prilagodbu visokoproizvodnih Sahiwal i Karan Fries krava u prijelaznom razdoblju. Hematološke promjene su uključile hemoglobin, volumen eritrocita (PCV), ukupan broj eritrocita (TEC), eritrocitne pokazatelje, ukupan broj leukocita (TLC) i diferencijalni broj leukocita (DLC), a metaboličke prilagodbe glukozu, urea-nitrat u krvi (BUN), neesterificirane masne kiseline (NEFA) i kolesterol. Prikupljeni su uzorci krvi od 8 gravidnih krava križanki Karan Fries i 8 gravidnih krava pasmine Sahiwal. Uzorci su prikupljeni na dane -15., -7., 0. (dan teljenja), +7. i +15. nakon teljenja. Koncentracija hemoglobina, PCV i TEC znakovito su porasli $(\mathrm{P}<0,01)$ do dana teljenja, da bi se poslije teljenja postupno smanjivali sve dok nisu postignute prijeporođajne vrijednosti. Dok je TLC, broj neutrofila i monocita porastao $(\mathrm{P}<0,01)$, broj limfocita znakovito se smanjio $(\mathrm{P}<0,01)$ na dan teljenja te je poslije teljenja postigao prijeporođajne vrijednosti. Nije bilo znakovitih učinaka na eritrocitne pokazatelje. Razine glukoze u krvi, BUN i NEFA pokazali su porast $(\mathrm{P}<0,01)$ od dva tjedna prije porođaja do dana teljenja, a zatim su se nakon teljenja smanjili na prijeporođajne vrijednosti. Za razliku od ostalih pokazatelja, razina kolesterola u plazmi dosljedno je rasla od drugog tjedna prije porođaja do dva tjedna poslije porođaja. Zaključno, rezultati našeg istraživanja nedvojbeno su pokazali određen obrazac hematološke i metaboličke prilagodbe visokoproizvodnih mliječnih krava u prijelaznom razdoblju od prije porođaja do poslije porođaja.

Ključne riječi: mliječne krave; hematološki pokazatelji; metabolički pokazatelji; poslijeporođajno razdoblje; prijelazno razdoblje 
